\title{
Fishery and estimation of potential yield of Bombayduck Harpadon nehereus (Hamilton, 1822) along Gujarat coast, India
}

\author{
VINAYA KUMAR VASE ${ }^{1}$, RAJAN KUMAR ${ }^{1}$, A. D. NAKHWA ${ }^{4}$, SHIKHA RAHANGDALE ${ }^{1}$, \\ J. JAYASANKAR ${ }^{2}$, K. MOHAMMED KOYA ${ }^{2}$, D. DIVU' ${ }^{1}$ AND PRATHIBHA ROHIT ${ }^{3}$ \\ ${ }^{1}$ Veraval Regional Centre of ICAR-Central Marine Fisheries Research Institute, Veraval - 362 269, Gujarat, India \\ ${ }^{2}$ ICAR-Central Marine Fisheries Research Institute, Ernakulam North, P. O., Kochi - 682 018, Kerala, India \\ ${ }^{3}$ Mangalore Research Centre of ICAR-Central Marine Fisheries Research Institute, Mangalore - 575001 \\ Karnataka, India \\ ${ }^{4}$ Mumbai Research Centre of ICAR-Central Marine Fisheries Research Institute, Versova, Mumbai - 400061 \\ Maharashtra, India \\ e-mail:v.vinaykumarvs@gmail.com
}

\begin{abstract}
Bombayduck Harpadon nehereus (Hamilton, 1822) is one of the key fishery resources landed along the Indian coast with uniqueness in distribution and exploitation. The resource is known for discontinuous distribution, majorly along the northwest and north-east coasts of India. Gujarat is the lead state to contribute nearly $64.72 \%(72,949$ t) to the total national landings of the resource $(11,2705 \mathrm{t})$ in 2018 . Dolnet gear contributes nearly $95 \%$ of the total landings of the resource in the region. The landings and the corresponding catch per unit effort (CPUE) showed a fluctuating trend over the study period of 1994-2014. The catches fluctuated between 35,235 t (2016) and 92,188 t (2004), whereas the CPUE oscillated in the range of 15 to $20 \mathrm{~kg} \mathrm{~h}^{-1}$ (1998) and $30.76 \mathrm{~kg} \mathrm{~h}^{-1}$ (2003). The period of 1994-2000 was the most productive period with an average catch of $72,133 \mathrm{t}$, whereas the succeeding decade was the leanest phase with an average annual catch of $50,035 \mathrm{t}$. The estimated potential yield (= maximum sustainable yield, MSY) was estimated at 73,700 $\mathrm{t}$ and 70,108 $\mathrm{t}$ using the Bayesian surplus production model (CMSY \& BSM) and basic Schaefer surplus production model respectively. The present catch and exploitation levels were found to be close to the optimum level and a further increase in effort for the resource is not recommended.
\end{abstract}

Keywords: Bombayduck, BSM, CMSY, Harpadon nehereus, Median catch, Surplus production model

\section{Introduction}

The Bombayduck Harpadon nehereus (Hamilton, 1822 ) is a unique fishery resource with discontinuous distribution along the Indian coast. The availability is restricted along the north-west and north-east coasts of India. North-west coast of India contributes to bulk of the total Bombayduck landings. Fishery for the resource is traditional to the state of Gujarat, especially along the south Gujarat and Saurashtra region, where the resource is harvested using a specialised type of bag net referred to as dolnet. The species is locally called as Bumla or Bumli and is preferred in fresh, salted and dried form. Laminated version of dried Bombayduck is a preferred commodity, especially in the north and north-eastern states of India (Kurian, 2000; Jaiswar and Chakraborty, 2016). With a long history of exploitation, unique distribution pattern and harvesting method, it has attracted various researchers who studied the life history, fishery pattern, stock structure and status of the resource. Gujarat, especially the Saurashtra coast has been one of the most preferred places for the study of the fishery and biology of the species in India. Bapat $(1967,1970)$ has established the fact that the stocks harvested in both Gujarat and Maharashtra coasts are not similar, hence they need separate management strategies. Since then, several parallel studies have been conducted on the species along both the coasts. Several works on feeding biology (Khan et al., 1992; Ghosh et al., 2009), reproductive biology, age, growth and mortality (Khan, 1989; Khan et al., 1992; Ghosh et al., 2009; Ghosh, 2014) were carried out for the resource along the Gujarat coast.

The fishery of Bombayduck, though has been underexploited for a long time, currently needs periodic assessment on the health status of the stocks with everincreasing fishing pressure. It is even more important to investigate the fisheries when the catches are fluctuating in combination with a reduction in catch per unit effort. The technical strategy to assess the health of the stock is to estimate the potential yield or maximum sustainable yield (MSY) for the resource and compare with the present catch or yield. The results will help us to understand the current 
level of exploitation and formulate appropriate strategies to harvest the resource at a sustainable level without compromising the yield from the resources in the future. Several attempts have been made in the past to estimate the MSY for the resource in the region (Khan, 1989; Khan et al., 1992; Ghosh et al., 2009), but none of them have any bearing on the regulation of the fishery in the region. Technically, the MSY at a given time is a function of the biomass, which is dynamic and hence a periodic assessment is required, especially when the fishery is unregulated in terms of effort spent, as in the current situation. The present study is an attempt to estimate the potential yield for the resource using different models or approaches, a relative comparison of model outputs and further to propose a more realistic estimate of maximum sustainable yield and corresponding fishing effort.

\section{Materials and methods}

The present work was conducted as a part of the study aimed at working out the potential yield for the marine capture fisheries using multiple approaches and compare those outputs to give more reasonable estimates. The current estimates were based on catch and effort data for Bombayduck, available with the National Marine Living Resource Data Centre (NMLRDC) of the ICAR-Central Marine Fisheries Research Institute, Kochi. The gearwise catch and effort data for a period of 1994-2017 were used as input data to arrive at the estimates. The fishing ground for this resource has very narrow spatial expansion and are restricted mostly with a spatial spread of $20^{\circ}$ and $21^{\circ} \mathrm{N}$ latitude and $070^{\circ}$ and $072^{\circ} \mathrm{E}$ longitude along south Gujarat and $22.5^{\circ}$ and $23.5^{\circ} \mathrm{N}$ latitude and $068^{\circ}$ and $069^{\circ} \mathrm{E}$ longitude along north Gujarat (Fig. 1).

The cumulative effort may not yield desirable estimates in the case of multi-species and multi-gear fisheries like ours. Hence, the effort was standardised using a multi-step routine (Varghese et al., in press) as detailed below:

In a time series catch, the annual catch of a species is represented as:

$$
\mathrm{C}_{\mathrm{ijk}}=\text { catch of } \mathrm{i}^{\text {th }} \text { species by } \mathrm{j}^{\text {th }} \text { gear in } \mathrm{k}^{\text {th }} \text { year }
$$

where, $\mathrm{i}=1,2,3, \ldots \ldots \ldots \ldots . . . \mathrm{Ns} ; \mathrm{j}=1,2,3, \ldots \ldots \ldots . . . \mathrm{Ng}$; $\mathrm{k}=1,2,3, \ldots \ldots \ldots . . \mathrm{Ny}$

The proportionate contribution $\left(\mathrm{CP}_{\mathrm{ijk}}\right)$ of the $\mathrm{i}^{\text {th }}$ species in $\mathrm{j}^{\text {th }}$ gear in $\mathrm{k}^{\text {th }}$ year can be estimated as:

$$
\mathrm{CP}_{\mathrm{ijk}}=\mathrm{C}_{\mathrm{ijk}} / \sum_{\mathrm{i}=1}^{\mathrm{Ns}} \mathrm{C}_{\mathrm{ijk}}
$$

Subsequently, the weight $\left(\mathrm{W}_{\mathrm{ij}}\right)$ for the $\mathrm{i}^{\text {th }}$ species, group for $\mathrm{j}^{\text {th }}$ gear for a given time series is calculated as:

$$
\mathrm{W}_{\mathrm{ij}}=\frac{\mathrm{CP}_{\mathrm{ijk}}}{\left.\operatorname{Var}\left(\mathrm{CP}_{\mathrm{ijk}}\right)+1\right]} / \sum_{\mathrm{j}=1}^{\mathrm{Ng}}\left[\operatorname{Var}\left(\mathrm{CP}_{\mathrm{ij}}\right)+1\right] \text {, }
$$

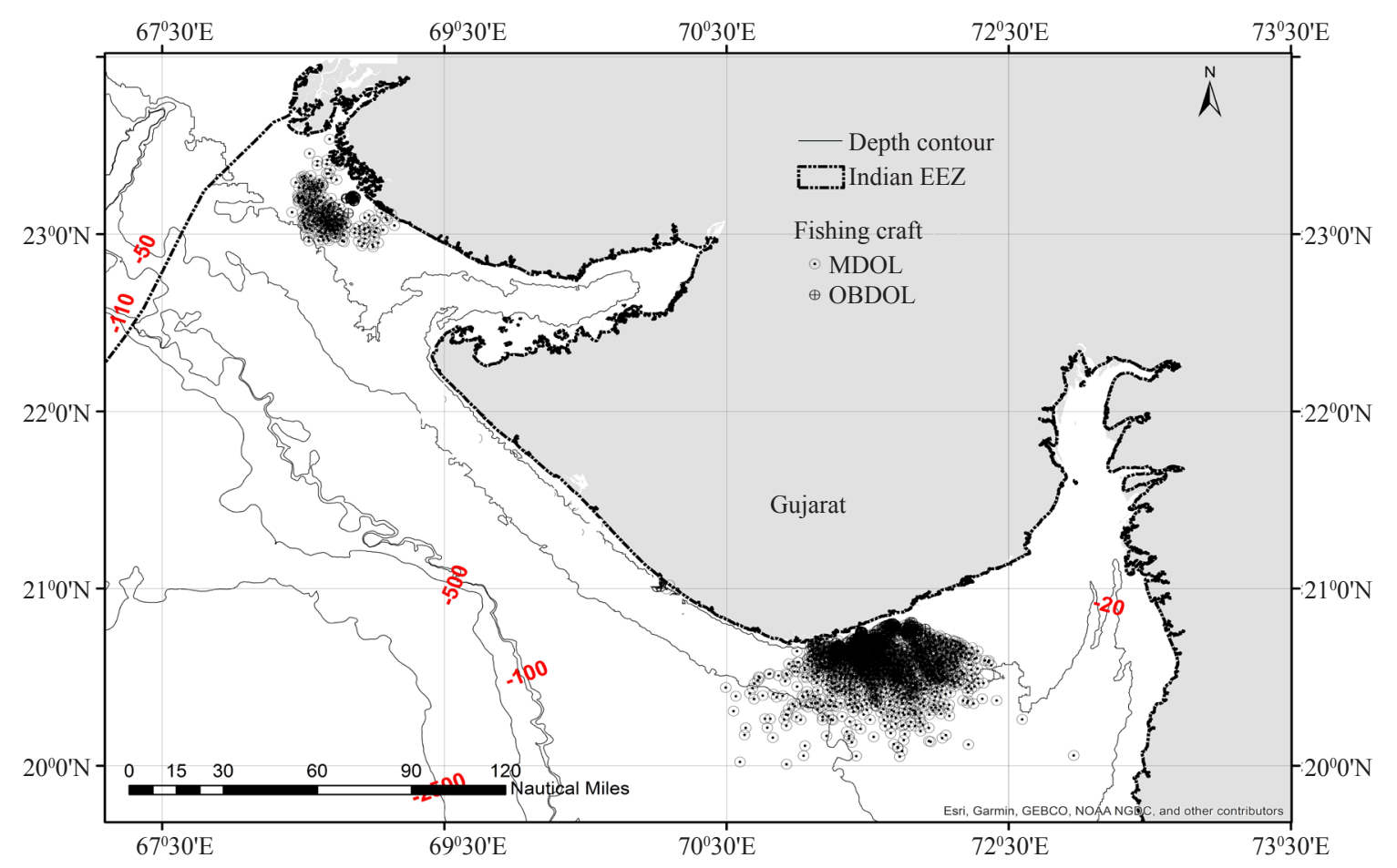

Fig. 1. Spread of fishing points by dolnets in key landing centers along the coast of Gujarat. MDOL: Mechanised dolnet, OBDOL: Outboard dolnet 
The weighted effort $\left(\mathrm{WE}_{\mathrm{ijk}}\right)$ for $\mathrm{i}^{\text {th }}$ species, $\mathrm{j}^{\text {th }}$ gear and $\mathrm{y}^{\text {th }}$ year is:

$\mathrm{WE}_{\mathrm{ijk}}=\mathrm{W}_{\mathrm{ij}} \times \mathrm{CP}_{\mathrm{ijk}} \times \mathrm{E}_{\mathrm{jk}}$, where $\mathrm{E}_{\mathrm{jk}}$ is effort of $\mathrm{j}^{\text {th }}$ gear in $\mathrm{k}^{\text {th }}$ year

Catch per unit effort (CPUE) for gear $\mathrm{j}$ in year $\mathrm{k}$ can be estimated as:

$$
\mathrm{CPUE}_{\mathrm{jk}}=\sum_{\mathrm{i}=1}^{\mathrm{Ns}} \mathrm{C}_{\mathrm{ijk}} / \mathrm{E}_{\mathrm{ijk}}
$$

The standardising factor $\left(\mathrm{SF}_{\mathrm{ij}}\right)$ for the species group $\mathrm{i}$ and gear $\mathrm{j}$ can be worked out as:

$\mathrm{SF}_{\mathrm{ij}}=\mathrm{CPUE}_{\mathrm{jk}} / \mathrm{CPUE}_{\mathrm{r}}$, where $\mathrm{CPUE}_{\mathrm{r}}$ is the mean for random gear.

The standardised effort of the $\mathrm{i}^{\text {th }}$ species groups, $\mathrm{j}^{\text {th }}$ gear in $\mathrm{y}^{\text {th }}$ gear can then be written as:

$\mathrm{SE}_{\mathrm{ijk}}=\mathrm{SF}_{\mathrm{ij}} \times \mathrm{WE}_{\mathrm{ijk}}$

The final standardised effort $\left(\mathrm{SE}_{\mathrm{i} k}\right)$ of the $\mathrm{i}^{\text {th }}$ species for a given year is arrived by summing across different gears as:

$$
\mathrm{SE}_{\mathrm{jk}}=\sum_{\mathrm{j}=1}^{\mathrm{Ng}} \mathrm{SE}_{\mathrm{ijk}}
$$

Surplus production models were used for the estimation of potential yield (=MSY). The basic Schaefer (1954) and Fox (1970) surplus production models were fitted with the catch and standardised effort to estimate MSY, $\mathrm{F}_{\mathrm{MSY}}, \mathrm{B}_{\mathrm{MSY}}$ and $\mathrm{r}$. A Bayesian version of the surplus production model (CMSY and BSM) using only catch and resilience as input (Froese et al., 2017) was also used to estimate the above quoted parameters. The basic surplus production model parameters were estimated using the prod_mod_ts module under the Trop Fish R package (Mildenberger et al., 2017) for fish stock assessment in $\mathrm{R}$. The Bayesian surplus production model was run using R-script CMSY_O_7q.R (http://oceanrep.geomar. de/33076/). Both the approaches were run using $\mathrm{R}$ studio (https://www.rstudio.com/). An alternate approach was attempted using a recent median catch for the last ten years (SAFMC, 2011; Carruthers et al., 2014) as an estimate of maximum sustainable yield.

\section{Results}

Dolnet is the dominant fishing gear to exploit Bombayduck resources along the Gujarat coast, which accounted for $94.84 \%$ of the total landings in the year 2018. Trawlers are the second most dominant gear, which contributed only $4.20 \%$ of the total catch of Bombayduck (Fig. 2). Throughout the study period (1994-2017), dolnet was the most dominant gear to contribute to the Bombayduck landings. In some years, the trawlnet contribution to the total landings surpassed by $10 \%$, mostly during the last decade (2001-2010). In recent years, gillnetters are also found to harvest the resource, but in meagre quantity on an occasional basis. The contributions of the other gears are negligible in the last one and half decade, but in the 1990s (1994-2000) smaller quantities upto $10 \%$ were landed by these gears (Fig. 3).

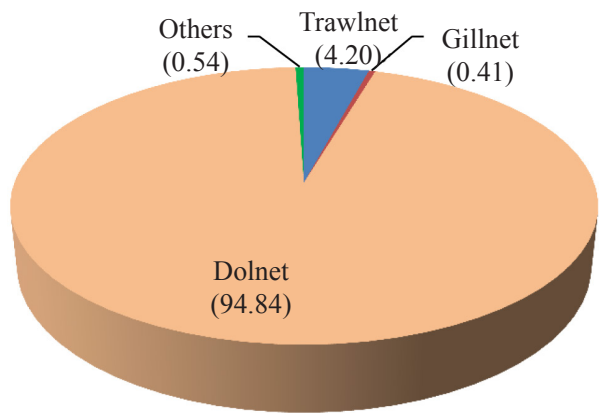

Fig. 2. Gear-wise percentage contribution of Bombayduck along the Gujarat coast, India

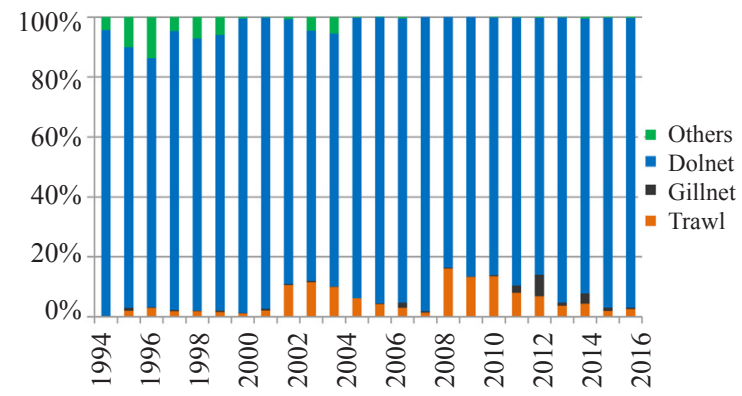

Fig. 3. Gear decomposed (on \% basis) catch data of Bombayduck along the Gujarat coast, India

The landings of Bombayduck in Gujarat showed significant fluctuations over the study period, with a maximum of $92,188 \mathrm{t}$ in the year 2004 and a minimum of $35,235 \mathrm{t}$ in 2016 . The average landings for the entire study period were estimated at 62,245 t. The effort spent to harvest this particular resource oscillated between 13,44,938 $\mathrm{h}$ (2015) and 49,41,280 h (2009). The average effort for the period from 1994-2017 was 29,13,752 h. The abundance index, CPUE $\left(\mathrm{kg} \mathrm{h}^{-1}\right)$ ranged between 15.20 in 1998 to 30.76 in 2003. The mean CPUE was estimated at $22.07 \mathrm{~kg} \mathrm{~h}^{-1}$ with a standard error of $1.03 \mathrm{~kg} \mathrm{~h}^{-1}$. The decade-wise analysis revealed, 1990s as the most productive period with average landings of $72,133 \mathrm{t}$ and CPUE of $25.67 \mathrm{~kg} \mathrm{~h}^{-1}$. On the contrary, with the lowest CPUE of $18.49 \mathrm{~kg} \mathrm{~h}^{-1}$, the period from 2001 to 2010 was the lean phase for the fishery. The fishery is quite a magnum in the region with an average annual production of 50,035 t. The present decade average (2011-2017) is close to that of the 1991-2000, both in terms of catch and realised CPUE (Table 1). 
Table1. Descriptive statistics for the time series catch and effort data on Bombayduck fisheries of Gujarat, India

\begin{tabular}{llll}
\hline Parameters & Std. Effort $(\mathrm{h})$ & Catch $(\mathrm{t})$ & $\left.\mathrm{CPUE}_{(\mathrm{kg} \mathrm{h}}{ }^{-1}\right)$ \\
\hline Mean & 2913752 & 62245 & 22.07 \\
Standard error & 161928 & 3109 & 1.03 \\
Median & 2848894 & 61972 & 21.74 \\
Minimum & 1344938 & 35235 & 15.20 \\
Maximum & 4941280 & 92188 & 30.76 \\
Mean (1994-2000) & 2817103 & 72133 & 25.67 \\
Mean (2001-2010) & 2836048 & 50035 & 18.49 \\
Mean (2011-2017) & 3121407 & 69800 & 23.60 \\
\hline
\end{tabular}

Surplus production models were applied for estimation of MSY for Bombayduck using catch and effort data either alone or in combination. The MSY estimated by different approaches were: $73,700 \mathrm{t}$ (CMSY), $70,108 \mathrm{t}$ (Schaefer surplus production model), 1,28,284 $\mathrm{t}$ (Fox surplus production model) and 58,717 t (median catch). The ratio of the current effort and effort required to achieve MSY was close to unity $\left(\mathrm{F} / \mathrm{F}_{\mathrm{MSY}}=0.98\right)$ as per Bayesian surplus production model estimates. The $\mathrm{F}_{\mathrm{MSY}}$ was estimated at $0.275,0.340$ and 0.815 using CMSY, Schaefer model and Fox model respectively (Table 2). The yield curve, viable $\mathrm{r}-\mathrm{k}$ combination, biomass with confidence range and equilibrium curve are presented in Fig. 4. B/BMSY against $\mathrm{F} / \mathrm{F}_{\mathrm{MSY}}$ curve for CMSY method are depicted in Fig 5. Among surplus production models, Schaefer model graphical outputs viz., biomass, CPUE (both observed and predicted) and yield curve are presented in Fig. 6.

\section{Discussion}

Bombayduck is harvested along the north-west coast of India using a fixed bag net known as dolnet. The method of fishing is unique, as the fishing mainly depends on the tidal current for the capture and retention of fishes. The nets are set with the opening, or mouth of the net against the strong tidal current and as a result, the fish flows into the net and the tidal current helps in retaining the fish inside the net, therefore hauling can be made after the turn of the tide. The method of operation of dolnet along the north-west coast has been described by Gokhale (1957). But since then the net and its operation have undergone many changes, like mechanisation of the crafts used and introduction of synthetic fibers which has substantially improved the capture efficiency of the gear (Raje and Desmukh, 1989). The fishing method with the above mentioned modifications and upgradation has continued to
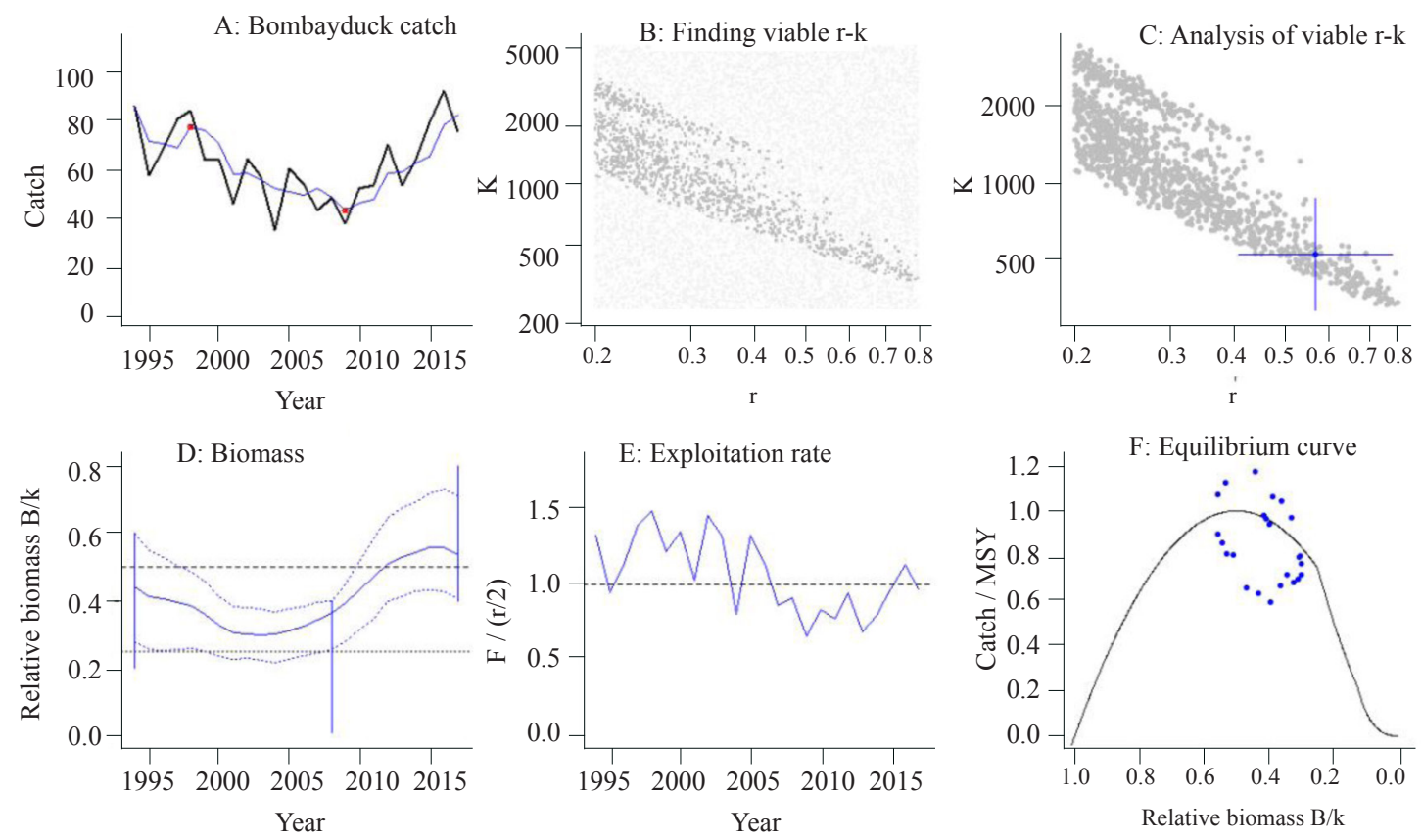

Fig. 4. The output of CMSY depicting time series catch, biomass, exploitation rate, catch-biomass equilibrium curve and viable r-k combinations 
Table 2. Output of different models/approaches applied for the estimation of potential yield (=MSY) of Bombayduck fisheries in Gujarat, India

\begin{tabular}{lllll}
\hline \multirow{2}{*}{ Method } & \multicolumn{3}{c}{ Output } \\
\cline { 2 - 5 } & $\mathrm{r}$ & $\mathrm{MSY}(\mathrm{t})$ & $\mathrm{F}_{\mathrm{MSY}}$ & $\mathrm{F}_{\mathrm{MSY}}$ \\
\hline CMSY (Bayesian method) & 0.55 & 73,700 & 0.98 & 0.275 \\
Schaefer Model & 0.68 & 70,108 & 0.340 \\
Fox Model & 2.22 & $1,28,284$ & $2,68,000$ \\
Recent median catch (10 years) & & 58,717 & 5.815 \\
\hline
\end{tabular}

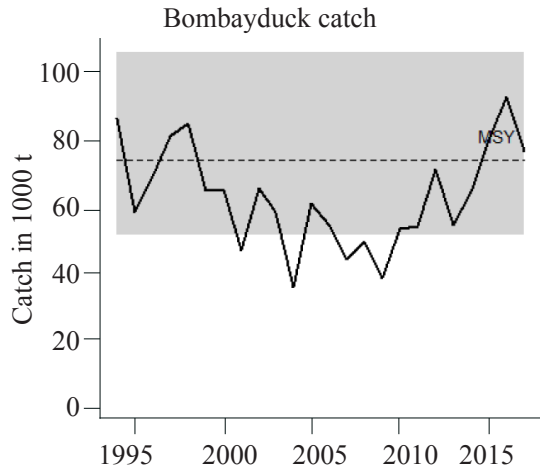

(a)

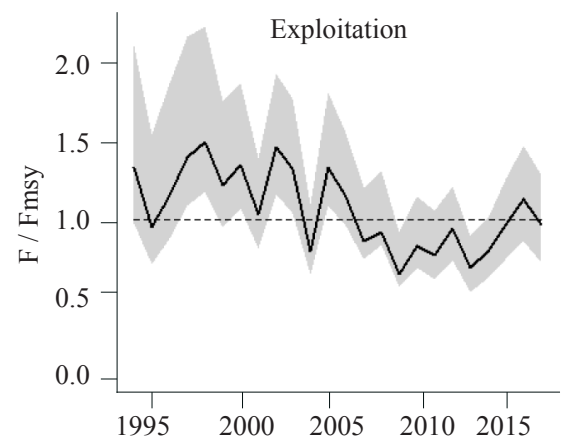

(c)

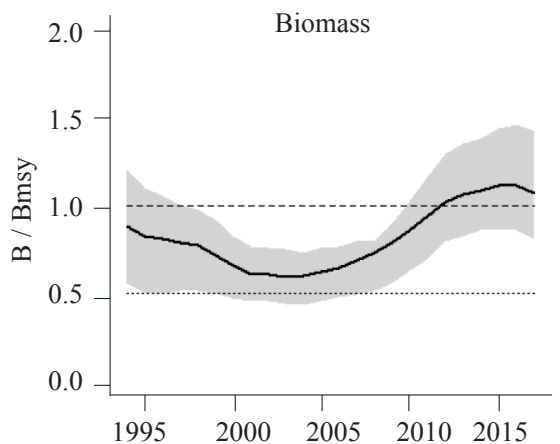

(b)

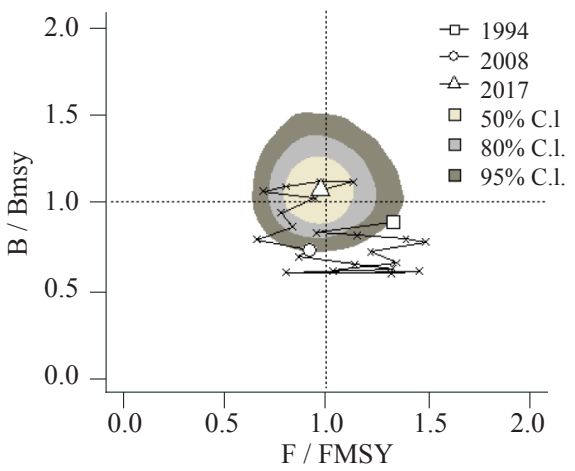

(d)

Fig. 5. The output of CMSY depicting (a) time series catch against MSY, Inter-annual variation in (b) B/BMSY, (c) F/FMSY and (d) B/BMSY against F/FMSY

be the major contributor (almost 95\% in 2018) towards the landings of Bombayduck in the state. Historically, the gear has been contributing more than $90 \%$ of the total landings of the resource barring a few years, when contribution of the other gear was marginally above $10 \%$ (Fig. 3). One of the reasons for such a significant contribution of this gear is the area of operation with the high tidal current. The area of operation as depicted in Fig. 1 shows that the fishery is highly localised and that the total effort spent by other gears (like trawl) in the region is very low especially along south Gujarat.

Bombayduck forms traditional fishery in the region and is consumed both in fresh and dried salted form. The resource has been under the thrust of high fishing pressure for long and hence, an assessment of the stock and estimation of potential yield (MSY) is very important. The holistic models with lesser data input form an ideal method when long-term impacts are to be assessed. The catch and effort data were utilised either alone or in combination for the estimation of potential yield. The Bayesian state-space surplus production model (CMSY and BSM) was used to determine the maximum sustainable yield, which was estimated at 73,700 t. The estimate of MSY from the basic Schaefer surplus production model was $70,108 \mathrm{t}$, which is quite similar to the output of CMSY. The estimate of MSY from the Fox model was much higher $(1,28,284 \mathrm{t})$ but the model fit was very poor and non-significant $\left(R^{2}<0.10\right)$. The median catch for the last ten years was estimated at $58,717 \mathrm{t}$, which is marginally lower than the MSY estimates of BSM and basic Schaefer model (Table 2).

The output of the first two approaches can be proposed as the potential yield for the resource in the 


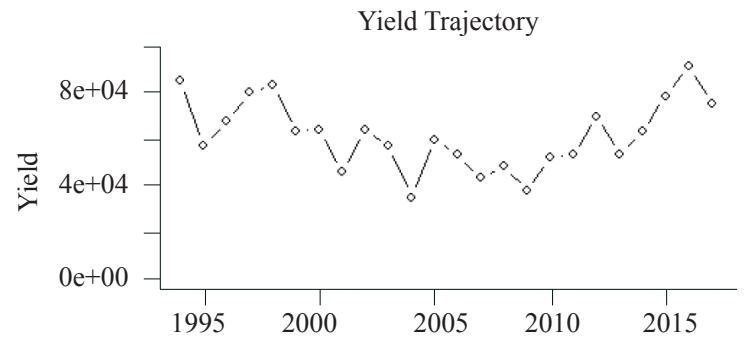

(a)

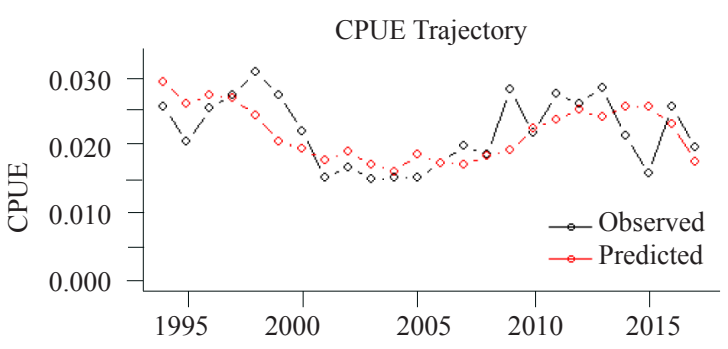

(c)

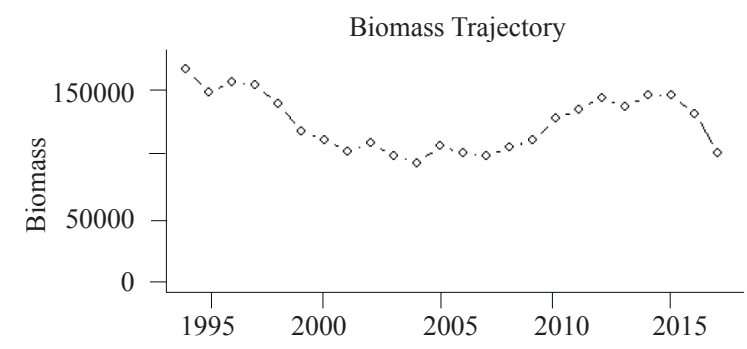

(b)

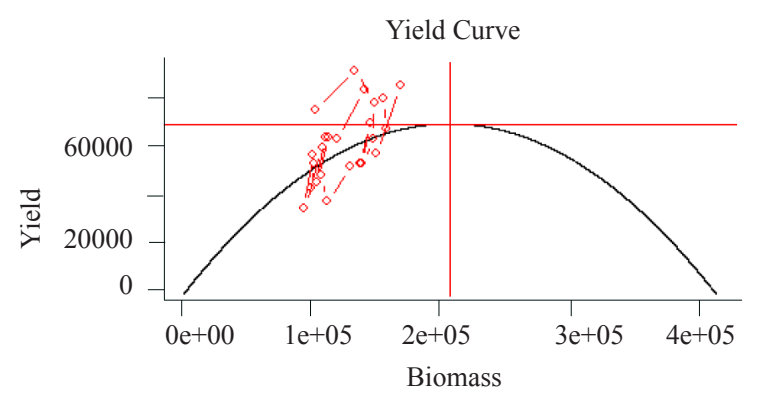

(d)

Fig. 6. Output of Schaefer surplus production model depicting (a) time series catch, (b) biomass, (c) observed and estimated CPUE and (d) yield-biomass curve.

region. Nevertheless, in the case when a more conservative approach is required in the backdrop of changing climate and fluctuating nature of the fishery, recent median catch as the potential yield or allowable catch for the resource can be adopted. The $\mathrm{F}_{\text {curr }} / \mathrm{F}_{\text {MSY }}$ was estimated at 0.98, which rules out any further increase in fishing effort for the optimum utilisation of the resource. The $\mathrm{Y}_{\text {curr }}$ / MSY was found to be marginally above the value of unity, indicative of optimum utilisation and therefore, no further intensification of the harvest is recommended if the stock is to be sustained. Previous estimates of MSY for the fishery from the coast ranged between 23,557 t (Ghosh et al., 2009) and 44,066 t (Khan, 1989). The biomass curve for the resource (Fig. 4, 5 and 6), clearly indicates a dip since late 1990 and signs of recovery from mid-2000s. The near optimum utilisation of the resource prior to the present study period is evident from the estimates of exploitation rate by Khan $(1986,1989)$ which were marginally below the value of 0.5 .

The present level of biomass seemed to be higher than what was there at the beginning of the study period (1994). The level of present biomass is higher than the last two decades, which could be the reason for the elevated estimates of MSY (Fig. 4 and 5), than the estimates of Khan (1989); Khan et al. (1992) and Ghosh et al. (2009). The decline in exploitation rate since late 2000s till 2015 (Fig. 4), resulted in the build-up of biomass to support higher CPUE for the fishery in recent years when compared to previous decades (Table 2). The lower biomass during the early 2000s was attributed to the intensive fishing of
Acetes, one of the major prey item of Bombayduck as reported by Ghosh et al. (2009). However, the increase in biomass in subsequent years despite higher fishing pressure on Acetes in the region has contradicted the argument. In addition, the previous estimates have used non-standardised effort (in hours) for estimation of MSY, which may not be apt in this case, where large array of species are caught in a non-selective gear like dolnet. A standardised effort, which was arrived by considering the percentage of the relative catch of the given species to the total catch and annual variation in catch across all gears, as used in the present study would yield a more realistic estimate of potential yield. The Bombayduck resource is a classical example of discontinuous distribution in a limited latitudinal space and hence, a special emphasis is required to assess the stock status for the sustainable exploitation and to maintain healthy biomass to avoid population crash in coming years.

\section{Acknowledgments}

Authors are thankful to the Indian Council of Agricultural Research (ICAR), New Delhi; Dr. A. Gopalakrishnan, Director, ICAR-CMFRI, Kochi and Dr. T. V. Sathianandan, Head, Fishery Resources Assessment Division, ICAR-CMFRI, Kochi for the encouragement and support during the study period.

\section{References}

Bapat, S. V. 1970. The Bombayduck Harpadon nehereus (Ham.). Bull. Cent. Mar. Fish. Res. Inst., 21: 1-66. 
Bapat, S. V. 1967. The Bombayduck. In: $20^{\text {th }}$ Anniversary Souvenier. Central Marine Fisheries Research Institute, Mandapam, Tamil Nadu, India.

Carruthers, T. R., Punt, A. E., Walters, C. J., MacCall, A., McAllister, M. K., Dick, E. J. and Cope, J. 2014. Evaluating methods for setting catch limits in data-limited fisheries. Fish. Res., 153: 48-68. doi.org/10.1016/j. fishres.2013.12.014.

Fox Jr. W. W. 1970. An exponential surplus-yield model for optimising exploited fish populations. Trans. Am. Fish. Soc., 99(1): 80-88. doi.org/10.1577/1548-8659(1970)99< 80:AESMFO $>2.0 . \mathrm{CO} ; 2$.

Froese, R., Demirel, N., Coro, G., Kleisner, K. M. and Winker, H. 2017. Estimating fisheries reference points from catch and resilience, Fish Fish., 18: 506-526. doi.org/10.1111/ faf.12190.

Ghosh, S. 2014. Fishery, reproductive biology and diet characteristics of Bombayduck Harpadon nehereus (Ham.) from Saurashtra coast. Indian J. Fish., 43(3): 418-426.

Ghosh, S. and Pillai, N. G. K. 2009. Fishery and population dynamics of Harpadon nehereus (Ham.) off Saurashtra Coast. Indian J. Mar. Sci., 43(3): 418-426.

Gokhale, S. V. 1957. Operation of the dolnet off Saurashtra coast. J. Bombay Nat. Hist. Soc., 54: 714-725.

Jaiswar, A. K. and Chakraborty, S. K. 2016. A review on fishery, biology and stock parameters of Bombayduck Harpadon nehereus (Hamilton, 1822) occurring in India. J. Indian Fish. Ass., 43: 67-96.

Khan, Z. M., Kurup, K. N. and Lipton, A. P. 1992. Status of Bombayduck Harpadon nehereus (Ham.) resource off Saurashtra coast. Indian J. Fish., 39(4): 235-242.
Khan, Z. M. 1986. Mortality and stock estimates of Bombayduck Harpadon nehereus (Ham.) off Nawabunder (Gujarat). Indian J. Fish., 33(3): 354-358.

Khan, Z. M. 1989. Observation on the fishery of Bombayduck Harpadon nehereus (Hamilton) along the Saurashtra coast. Indian J. Fish., 36: 354-358.

Kurian, A. 2000. The Bombayduck: Stock status and response to exploitation. In: Pillai, V. N. and Menon, N. G. (Eds.), Marine fisheries research and management. Central Marine Fisheries Research Institute, Kochi, India. p. 349-363.

Mildenberger, T. K., Taylor, M. H. and Wolff, M. 2017. Trop Fish R: Tropical Fisheries Analysis with R_. R package ver, 1. Methods Ecol. Evol., 8: 1520-1527 doi: 10.1111/2041210X.1279.

Raje, S. J. and Deshmukh, V. D. 1989. On the dolnet operation at Versova, Bombay. Indian J. Fish., 36(3): 239-248.

SAFMC 2011. Comprehensive Annual Catch Limit (ACL): Amendments for the south Atlantic region. South Atlantic Fishery Management Council, South Carolina, USA.

Schaefer, M. B. 1954. Some aspects of the dynamics of the populations important to the management of commercial marine fisheries. Bull. Inter-Am. Trop. Tuna Comm. (I-ATTC), 1(2): 27-56.

Varghese, E., Sathianandan, T. V., Jayasankar, J., Kuriakose, S., Mini, K. G. and Muktha, M. (In Press) Bayesian statespace implementation of Schaefer production model for assessment of stock status for the multi-gear fishery. J. Indian Soc. Agric. Stat. 